\title{
A case of adult intussusception
}

\author{
Charlotte Skinner, ${ }^{1}$ Clare Coyle, ${ }^{1}$ Gareth Parkes, ${ }^{1}$ William Drake ${ }^{2}$
}

${ }^{1}$ Barts Health, Royal London Hospital, London, UK ${ }^{2}$ Department of Specialist Endocrine, London, UK

\section{Correspondence to} Dr Charlotte Skinner, cskinner@doctors.org.uk

Accepted 19 September 2015

\section{DESCRIPTION}

A 64-year-old man presented to hospital with collapse on a 2-month history of loose stool progressing to watery diarrhoea 2-3 times/day with unintentional weight loss of $30 \%$ of his body mass over 3 months. He had a history of treated lung sarcoidosis, epilepsy and bipolar syndrome. Physical examination revealed a cachectic patient with bipedal oedema but no organomegaly, and no

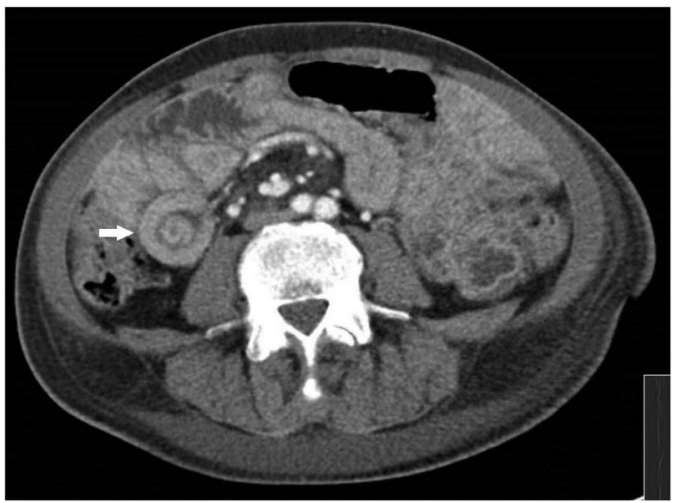

Figure 1 Axial plane showing a point of intussusception as a target lesion to the left of the image.

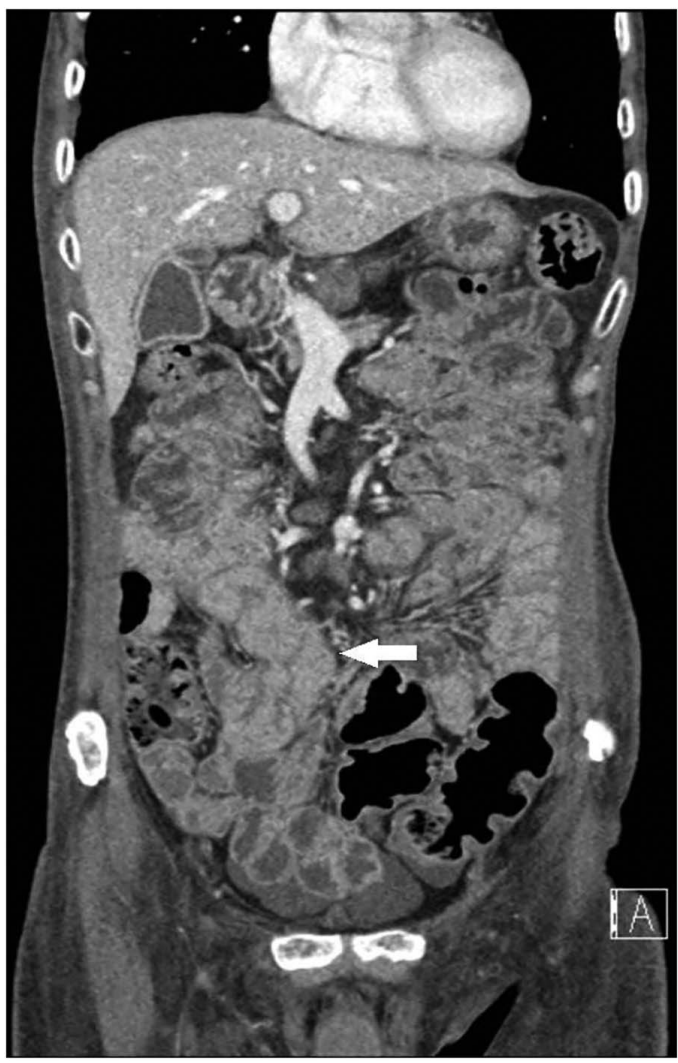

Figure 2 Coronal plane showing the intussusception as a pouch within a pouch to the bottom left of the image. abdominal mass or lymphadenopathy. Initial blood tests demonstrated an acute kidney injury, coagulopathy and hypoalbuminaemia. He had haemoglobin of $14.9 \mathrm{~g} / \mathrm{dL}$, haematocrit 0.42 , serum folate $3.6 \mathrm{mmol} / \mathrm{L}$ and ferritin of $298 \mu \mathrm{g} / \mathrm{L}$. A CT of the abdomen showed three separate points of intussusception within the ileum but with no evidence of proximal obstruction (figures 1-3). His blood tests showed tissue transglutamase $\operatorname{IgA}>200$ and positive endomysial IgA antibody. A subsequent duodenal biopsy confirmed the diagnosis of coeliac disease (Marsh classification 3c). He was commenced on a gluten-free diet and his symptoms resolved.

Intussusception in adults is rare and accounts for only $5 \%$ of all cases. However, of these, over $90 \%$ cases are secondary to an underlying pathological process, unlike in children where the majority are primary, benign cases with no underlying anatomical cause. ${ }^{1}$ The association between intussusception and coeliac disease was first described in 1978 . The clinical presentation is variable, often

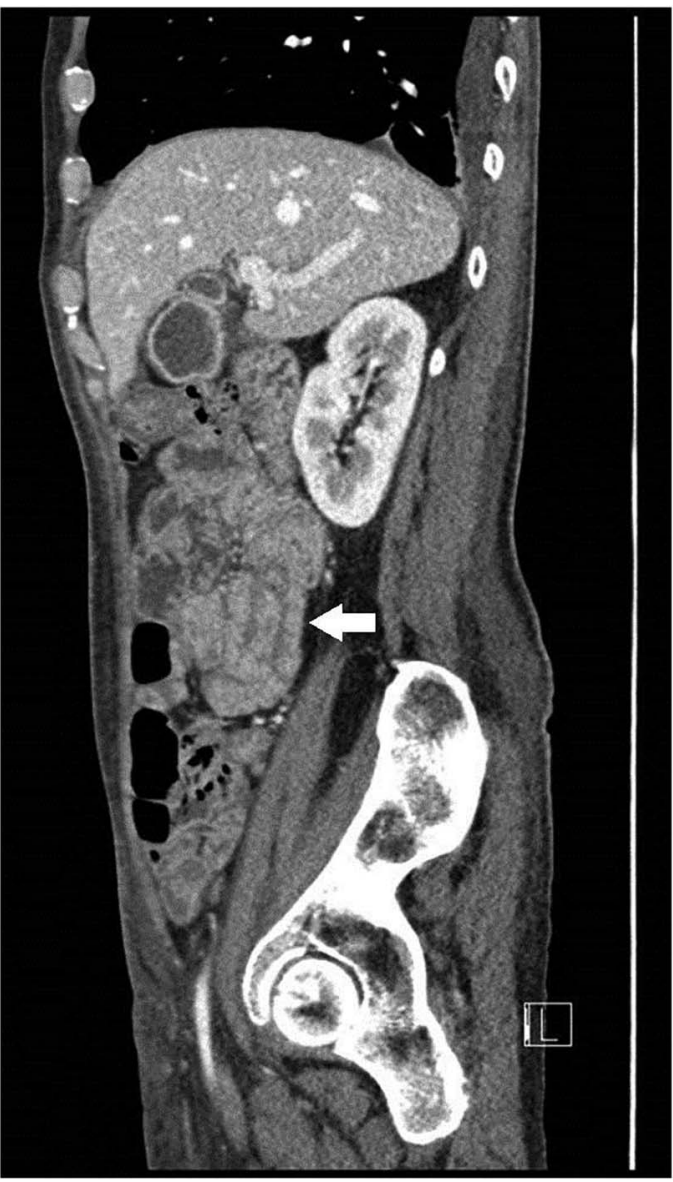

Figure 3 Sagittal plane showing another pouch within a pouch point of intussusception in the middle of the image. 
non-specific, and can be the initial presentation of coeliac disease, as in our case. Studies suggest these patients have more severe disease at diagnosis. ${ }^{2}$ Symptoms usually resolve on adherence to a gluten-free diet and surgical intervention is rarely needed.

\section{Learning points}

- Adult intussusception is rare but, when it occurs, it should be investigated as there is usually an underlying cause.

- The differential diagnosis includes small bowel and colorectal malignancy, polyps, Meckel's diverticulum and coeliac disease.

- Coeliac disease should be considered, as it is a common and treatable condition, and avoids the need for surgical intervention.
Acknowledgements The authors would like to acknowledge the Radiology Department at the Royal London Hospital for providing the images.

Contributors This article was written by CS and CC with editing contributions from Professor WD and GP.

Competing interests None declared.

Patient consent Obtained.

Provenance and peer review Not commissioned; externally peer reviewed.

\section{REFERENCES}

1 Marinis A, Yiallourou A, Samanides $L$, et al. Intussusception of the bowel in adults: a review. World J Gastroenterol 2009;15:407-11.

2 Gonda TA, Khan SU, Cheng J et al. Association of intussusception and celiac disease in adults. Dig Dis Sci 2010;55:2899-903.

Copyright 2015 BMJ Publishing Group. All rights reserved. For permission to reuse any of this content visit http://group.bmj.com/group/rights-licensing/permissions.

BMJ Case Report Fellows may re-use this article for personal use and teaching without any further permission.

Become a Fellow of BMJ Case Reports today and you can:

- Submit as many cases as you like

- Enjoy fast sympathetic peer review and rapid publication of accepted articles

- Access all the published articles

- Re-use any of the published material for personal use and teaching without further permission

For information on Institutional Fellowships contact consortiasales@bmjgroup.com

Visit casereports.bmj.com for more articles like this and to become a Fellow 